\title{
JENIS TUMBUHAN HUTAN YANG DIMANFAATKAN SEBAGAI BAHAN KERAJINAN OLEH SUKU DAYAK TAMAMBALOH DESA LABIAN KECAMATAN BATANG LUPAR KABUPATEN KAPUAS HULU
}

\author{
(Species Of Forest Plant That Used As A Craft Material By The Dayak Tamambaloh, Labian \\ Village, Batang Lupar District, Kapuas Hulu Regency)
}

\author{
MB. Bonnies Rollies Yoese, Dina Setyawati, Muflihati \\ Fakultas Kehutanan Universitas Tanjungpura Jl. Daya Nasional, Pontianak 78124 \\ E-mail : bonniesrolliesyoese@gmail.com
}

\begin{abstract}
Plants as natural resources were very diverse and abundant for various purposes, among others as a raw material for crafts. Dayak Tamambaloh tribe is a tribe that lived from one generation to the next generation in their customary areas which inseparable with the utilization of the forest plants specially as a craft material. The purpose of this research was to get the data and document of the species of forest plants that used as a craft material also to get know how the process of product produced by the Dayak Tamambaloh in Labian Village, Batang Lupar District, Kapuas Hulu Regency. The data was collected by interviewing the respondent and field survey. The result of this research found that there were 22 species of forest plant that utilized and 47 handicraft product that produced by the people of Dayak Tamambaloh, Labian Village, Batang Lupar District, Kapuas Hulu Regency.
\end{abstract}

Keywords: Craft Plants, Tamambaloh Tribe, Batang Lupar, Kapuas Hulu

\section{PENDAHULUAN}

Hutan adalah tempat terdapatnya keanekaragaman hayati jenis tumbuhan dan hewan yang sangat penting bagi kehidupan manusia. Tumbuhan hutan dimanfaatkan oleh manusia untuk bahan bangunan dan perabotan rumah tangga, bahan kosmetik, bahan pangan, bahan bakar, obat-obatan dan bahan kerajinan, serta masih banyak lagi manfaat lain dari tumbuhan hutan. Bagian tumbuhan yang umumnya dimanfaatkan antara lain kulit, batang, buah, bunga, daun, dan biji untuk bahan kerajinan (Sihombing, 2011).

Bahan kerajinan merupakan produk yang dihasilkan dari keterampilan tangan dari para pengerajin yang dapat dibuat dari bahan alam atau barang yang sudah jadi dan diolah menjadi suatu produk yang bisa dijual. Produk kerajinan yang berasal dari hutan biasanya dikenal dengan produk hasil hutan bukan kayu (HHBK). Tumbuhan hutan yang biasa digunakan berupa rotan, daun pandan, bambu. Tumbuhan ini dipanen oleh masyarakat langsung di hutan alam, kemudian diolah menjadi berbagi macam produk kerajinan yang mempunyai nilai jual atau dipakai sendiri contohnya pemukul tilam, keranjang ikan, topi tradisional, tikar dan masih banyak lagi produk kerajinan lainnya tergantung dari hasil kreativitas dan kreasi dari para pengerajin (Syukur, 2017).

Suku Dayak merupakan salah satu kelompok besar penduduk asli pulau 
Kalimantan (Patwanto, 2012). Dayak Tamambaloh merupakan suku Dayak yang tinggal dan bermukim di sepanjang aliran sungai Embaloh Kecamatan Embaloh Hulu, Sungai Palin Kecamatan Embaloh Hilir dan di sepanjang aliran sungai dan anak Sungai Labian Kecamatan Batang Lupar (Liberani, 2016). Masyarakat Desa Labian Kecamatan Batang Lupar Kabupaten Kapuas Hulu khususnya Dayak Tamambaloh masih menggunakan dan memanfaatkan tumbuhan hutan sebagai pemenuhan kebutuhan hidup dan sebagai bahan baku pembuatan kerajinan tangan. Pemanfaatan tumbuhan hutan sebagai bahan baku kerajinan tangan yang terdapat di Desa Labian, secara tidak langsung telah membantu perekonomian masyarakat setempat, khususnya kelompok pengrajin. Ciri khas dari kerajinan ini menggunakan bahan yang terdapat dari tumbuhan hutan dan dipadukan dengan manikmanik dan motif budaya lokal. Jenis tumbuhan yang paling sering digunakan untuk bahan kerajinan adalah rotan dan bambu, namun selain dua jenis tersebut masih banyak jenis tumbuhan lain yang dapat digunakan sebagai bahan kerajinan (Nono, 2017). Penelitian ini dilakukan untuk mendata dan mendokumentasikan jenis tumbuhan hutan yang dimanfaatkan sebagai bahan kerajinan dan cara pengolahan, pemanfaatan serta produk yang dihasilkan oleh suku Dayak Tamambaloh di Desa Labian
Kecamatan Batang Lupar Kabupaten Kapuas Hulu Provinsi Kalimantan Barat.

\section{METODE PENELITIAN}

Penelitian dilaksanakan di Desa Labian Kecamatan Batang Lupar Kabupaten Kapuas Hulu Provinsi Kalimantan Barat pada bulan Oktober hingga Desember 2018. Alat dan bahan penelitian adalah peta lokasi, kuisioner, buku identifikasi tumbuhan, dan alat perekam. Metode yang digunakan dalam penelitian ini adalah metode wawancara dan survey lapangan. Objek penelitian ini adalah masyarakat yang memanfaatkan tumbuhan hutan dan jenis tumbuhan yang digunakan. Teknik pengambilan data dilakukan dengan mewawancarai responden yang menggunakan tumbuhan hutan sebagai bahan kerajinan. Pemilihan responden dengan menggunakan teknik snowball sampling. Data disajikan dalam bentuk tabulasi dan dianalisis secara deskriptif.

\section{HASIL DAN PEMBAHASAN}

Hasil penelitian yang dilakukan di Desa Labian Kecamatan Batang Lupar Kabupaten Kapuas Hulu dengan mewawancarai 16 responden didapatkan 22 jenis tumbuhan hutan yang digunakan oleh masyarakat Dayak Tamambaloh sebagai bahan kerajinan yang ditemukan didalam dan di sekitar kawasan hutan (Tabel 1). Selain itu, ada beberapa jenis tumbuhan hutan yang sudah mulai dibudiyakan oleh masyarakat seperti arere pangkarabun, arere kaiyo, uwe retean, talope, sagu dan sisanya tumbuh liar di hutan. 
Tabel 1. Jenis Tumbuhan Hutan Yang Dimanfaatkan Sebagai Bahan Kerajinan (Species of Forest Plants Used as Craft Materials)

\begin{tabular}{|c|c|c|c|c|}
\hline No & $\begin{array}{c}\text { Nama Lokal } \\
\text { (2) }\end{array}$ & $\begin{array}{c}\text { Nama Ilmiah } \\
\text { (3) }\end{array}$ & $\begin{array}{l}\text { Bagian Yang } \\
\text { Digunakan } \\
\text { (4) }\end{array}$ & $\begin{array}{c}\text { Kerajinan } \\
\text { (5) }\end{array}$ \\
\hline 1 & $\begin{array}{l}\text { Arere } \\
\text { pangkarabun/Jali }\end{array}$ & Coix lacryma-jobi & Buah & Kalung, tas, gelang \\
\hline 2 & Arere kaiyo/Jali & Coix sp & Buah & $\begin{array}{l}\text { Syal, Kalung, tas, } \\
\text { gelang }\end{array}$ \\
\hline 3 & Ambulung/Sagu & Metroxylon sagu & $\begin{array}{l}\text { Kulit dahan dan } \\
\text { daun }\end{array}$ & Atap, bakul, aga'k \\
\hline 4 & $\begin{array}{l}\text { Bulo'k totoh/bambu } \\
\text { ampel }\end{array}$ & $\begin{array}{l}\text { Schizostzchyum } \\
\text { zollingeri Steud }\end{array}$ & Batang & Bubu, saroak \\
\hline 5 & $\begin{array}{l}\text { Bulo'k } \\
\text { patung/bambu } \\
\text { betung }\end{array}$ & $\begin{array}{l}\text { Dendrocalamus } \\
\text { asper (Schultes f.) } \\
\text { Backer ex Heyne }\end{array}$ & Batang & Bubu \\
\hline 6 & $\begin{array}{l}\text { Bulo'k } \\
\text { paring/bambu } \\
\text { pering }\end{array}$ & $\begin{array}{l}\text { Dendrocalamus } \\
\text { asper (Schultes f.) } \\
\text { Backer ex Heyne }\end{array}$ & Batang & Bubu, saroak \\
\hline 7 & Durian & $\begin{array}{l}\text { Durio zibethinus } \\
\text { Murr }\end{array}$ & Batang/kayu & Kepala parang \\
\hline 8 & Jangkang & Hornstedtia sp & Kulit dahan & Bakul, aga'k \\
\hline 9 & Kokorek & Archidendron sp & $\mathrm{Biji}$ & $\begin{array}{l}\text { Gantumgan kunci, } \\
\text { kalung }\end{array}$ \\
\hline 10 & Lita'k/pulai & $\begin{array}{l}\text { Alstonia scholaris } \\
\text { (L) }\end{array}$ & Batang/kayu & Perisai, tukuk tajak \\
\hline 11 & Limpaso/resam & $\begin{array}{l}\text { Dicranopteris } \\
\text { linearis }\end{array}$ & Batang/isi batang & Gelang \\
\hline 12 & Mamban/bemban & Donnax canniformis & Kulit batang & Aga'k, bakul \\
\hline 13 & Paripuk/pandan duri & Pandanus tectorius & Daun & $\begin{array}{l}\text { Salaben,topi,tas,sampul } \\
\text { buku, tikar, tanggoi }\end{array}$ \\
\hline 14 & Takalong/terap & $\begin{array}{l}\text { Artocarpus } \\
\text { odoratissimus }\end{array}$ & Batang/kayu & Kepala parang \\
\hline 15 & Talope & Ficus $s p$ & Biji & $\begin{array}{l}\text { Kalung, gantungan } \\
\text { kunci }\end{array}$ \\
\hline 16 & Taulean/ulin & $\begin{array}{l}\text { Eusideroxylon } \\
\text { zwageri }\end{array}$ & Batang/kayu & Sarung mandau \\
\hline 17 & $\begin{array}{l}\text { Uwe mataso/rotan } \\
\text { bubuai }\end{array}$ & $\begin{array}{l}\text { Plectocomia } \\
\text { elongata Martius ex } \\
\text { Blume }\end{array}$ & Batang & Keranjang, bakul, sabit \\
\hline 18 & $\begin{array}{l}\text { Uwe retean/rotan } \\
\text { sega }\end{array}$ & $\begin{array}{l}\text { Calamus caesius } \\
\text { Blume }\end{array}$ & Batang & $\begin{array}{l}\text { Keranjang, bakul, } \\
\text { sabit,tas, dompet }\end{array}$ \\
\hline & & & Batang & $\begin{array}{l}\text { Keranjang, bakul, } \\
\text { sabit, tas, dompet }\end{array}$ \\
\hline 19 & $\begin{array}{l}\text { Uwe sasut/rotan } \\
\text { korod }\end{array}$ & $\begin{array}{l}\text { Calamus heteroideus } \\
\text { Blume }\end{array}$ & Batang & $\begin{array}{l}\text { Keranjang, bakul, } \\
\text { sabit, tas, dompet }\end{array}$ \\
\hline 20 & $\begin{array}{l}\text { Uwe sisinik/rotan } \\
\text { dandan }\end{array}$ & $\begin{array}{l}\text { Calamus } \\
\text { Schistolantus Blume }\end{array}$ & Batang & $\begin{array}{l}\text { Keranjang, bakul, } \\
\text { sabit, tas, dompet }\end{array}$ \\
\hline 21 & $\begin{array}{l}\text { Uwe danan/rotan } \\
\text { dahan }\end{array}$ & $\begin{array}{l}\text { Korthalsia rigida } \\
\text { Blume }\end{array}$ & Batang & Keranjang, bakul, sabit \\
\hline 22 & $\begin{array}{l}\text { Uwe papatik/rotan } \\
\text { lilin }\end{array}$ & $\begin{array}{l}\text { Calamus javensis } \\
\text { Blume }\end{array}$ & Batang & Keranjang, bakul, sabit \\
\hline
\end{tabular}


Jenis tumbuhan hutan yang dimanfaatkan sebagai bahan kerajinan banyak ditemukan di sekitar kawasan hutan, hutan primer, hutan sekunder, tembawang, dan rawa-rawa. Bagian tumbuhan hutan yang paling banyak digunakan adalah bagian batang, buah, biji, kulit dan daun. Tumbuhan yang paling banyak dimanfaatkan untuk pembuatan produk kerajinan adalah tumbuhan rotan, dimana hampir disemua produk kerajinan menggunakan rotan untuk bahan baku pembuatan bakul, keranjang, dan alat pengikat. Menurut
Januminro (2000) bahwa keenam jenis rotan seperti rotan sega ( $C$. caesius Blume), rotan bubuai ( $P$. elongata Martius ex Blume), rotan korod ( $C$. heteroideus Blume), rotan dandan $(C$. Schistolantus Blume), rotan dahan ( $K$. rigida Blume), dan rotan lilin (C. javensis Blume) yang di temukan di Desa Labian dapat digunakan sebagai bahan pembuatan produk kerajinan.

Famili yang dimanfaatkan dari 22 jenis tumbuhan hutan oleh suku Dayak Tamambaloh didapatkan 12 famili (Grafik 1)

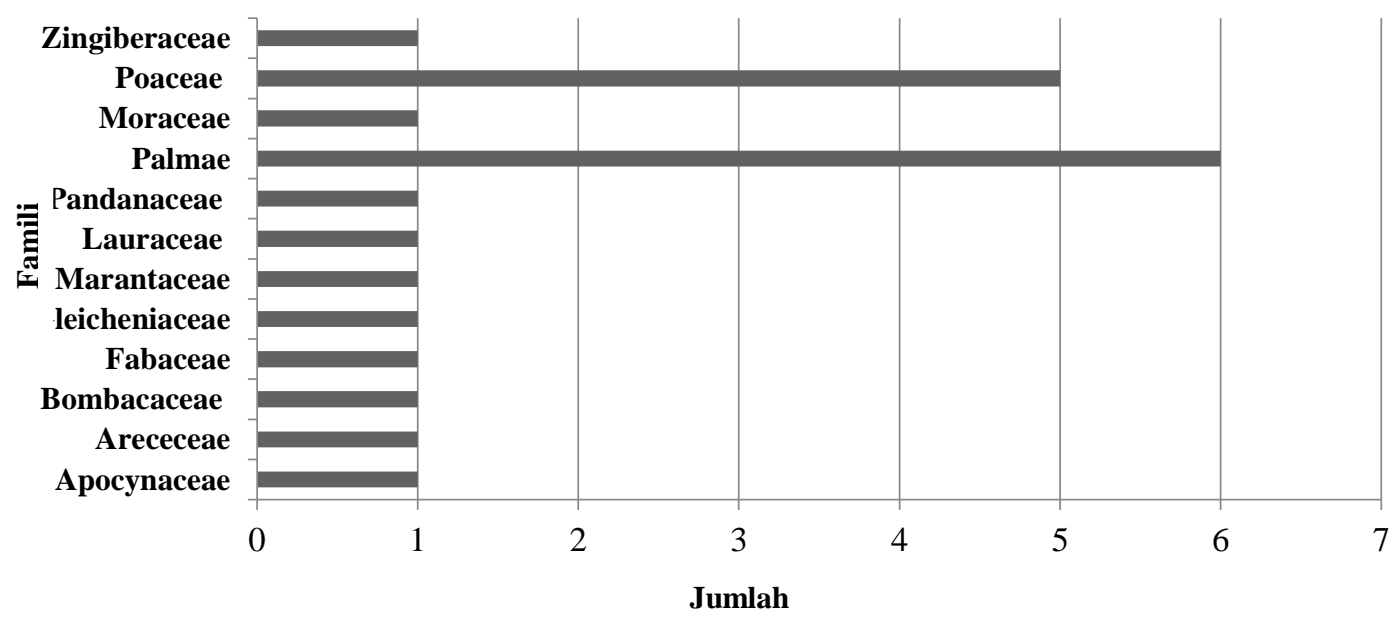

Grafik 1. Jumlah dan jenis tumbuhan hutan yang dimanfaatkan sebagai bahan kerajinan di Desa Labian Kecamatan Batang Lupar Kabupaten Kapuas Hulu (the number and species of forest plants used as handicraft materials in the Labian Village Batang Lupar District Kapuas Hulu Regency)

Diketahui famili yang paling banyak digunakan adalah famili palmae dengan jumlah individu 6 , poaceae 5 , apocynaceae dan famili lainnya berjumlah 1 .

Jenis tumbuhan yang digunakan oleh suku Dayak Tamambaloh Desa Labian Kecamatan Batang Lupar Kabupaten Kapuas Hulu Provinsi Kalimantan Barat adalah sebagai berikut.

\section{Jali}

Tumbuhan jali ada dua jenis yang digunakan sebagai bahan kerajinan yaitu Arere pangkarabun (Coix lacryma-jobi) dan arere kaiyo (Coix sp). Arere pangkarabun (Gambar 1) yang mempunyai arti merabunkan pengelihatan roh halus. Buah dari arere pangkarabun dibuat dalam bentuk gelang atau kalung yang dipakaikan untuk balita, yang dipercaya dapat mengusir roh halus yang 
ingin mengganggu anak-anak. Menurut Biji jali dimanfaatkan untuk bahan baku pembuatan kalung, gelang, tasbih, dan tirai yang sangat memikat dan menarik (Sholikhah et al, 2010) dalam (Irawanto et

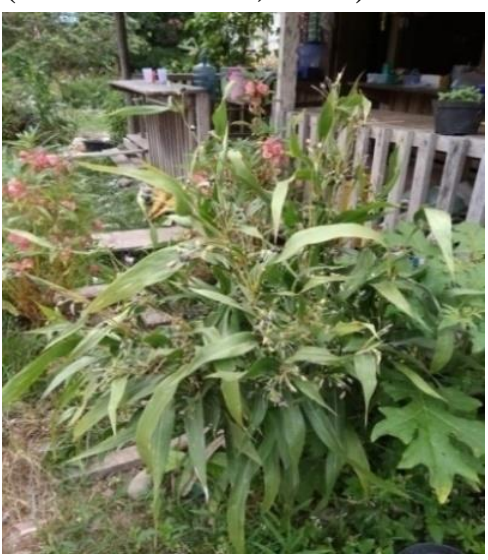

(a)

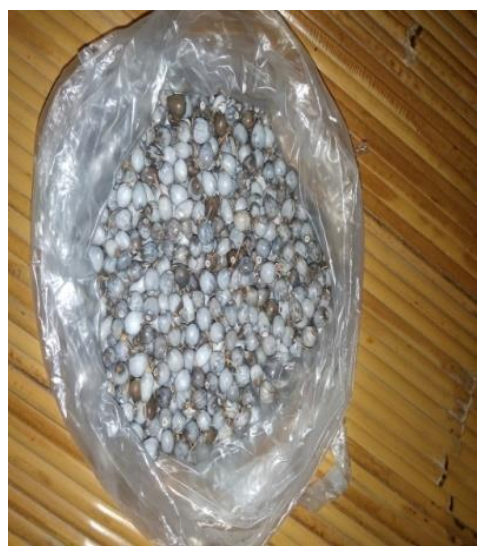

(b) $a l$, 2017). Biji jali yang berwarna abu-abu, keras, dan mengilap dimanfaatkan sebagai manik-manik untuk kalung, perhiasan, dan rosario (Irawanto et al, 2017).

Gambar 1. Tumbuhan jali dan produk kerajinan (a) Arere pangkarabun/Jali, (b) Buah jali, (c) Tas (jali plants and handicraft products (a) arere pangkarabun/jali, (b) jali fruit, (c) bag)

Tumbuhan jali dimanfaatkan oleh suku Dayak Tamambaloh sebagai bahan kerajinan gelang, kalung, tas, gantungan kunci. Proses pembuatan kerajinan dilakukan dengan cara menganyam setiap bagian buah dengan benang dan dipadukan dengan manik.

\section{Bemban (D.Canniformis)}

Tumbuhan bemban atau mamban (Gambar 2) dalam bahasa Dayak Tamambaloh merupakan salah satu tumbuhan yamg dimanfaatkan sebagai bahan kerajinan tangan seperti produk aga'k dan bakul (Liyanti, 2015).

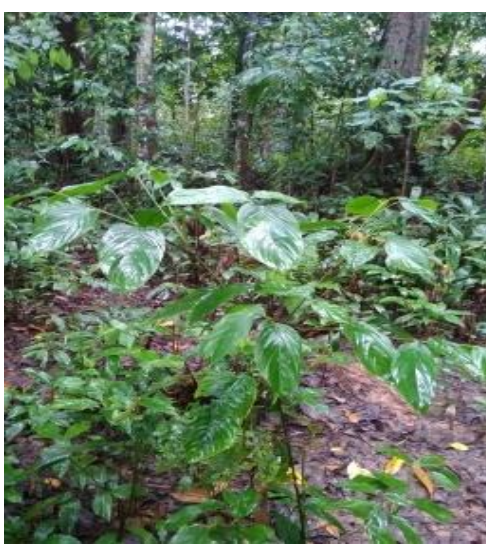

(a)

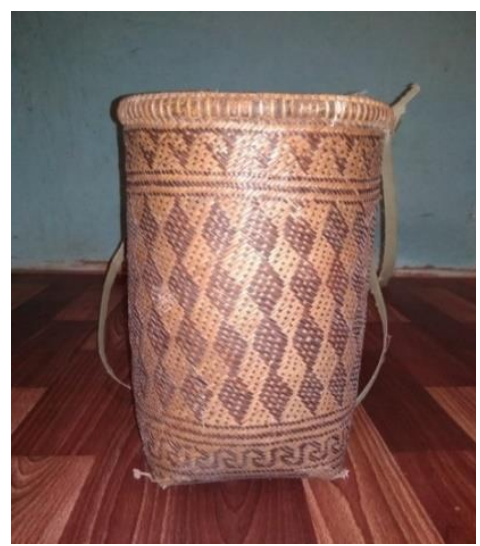

(b)

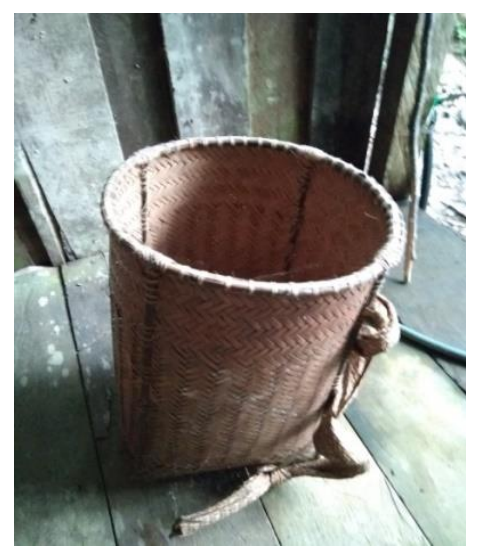

(c)

Gambar 2. Tumbuhan bemban dan produk kerajinan (a) Bemban, (b) Aga'k, (c) Bakul (bemban plants and handicrafts products (a) bemban, (b) aga'k, (c) bakul) 
Tumbuhan bemban dimanfaatkan sebagai kerajinan aga'k dan bakul. Bagian yang digunakan dari bemban adalah kulitnya dan cara pengolahannya dengan dianyam.

\section{Pandan duri (P. Tectorius)}

Tumbuhan pandan duri (Gambar 3) merupakan tumbuhan yang digunakan oleh Dayak Tamambaloh untuk membuat berbagai macam kerajinan tangan salah satunya seperti kerajinan Tikar, sampul buku dan salaben. Menurut (Sudana. 2017) pandan duri dimanfaatkan sebagai sebagai bahan pembuatan tikar yang digunakan untuk keperluan sehari-hari dan kerperluan ritual adat agama Hindu di Bali.

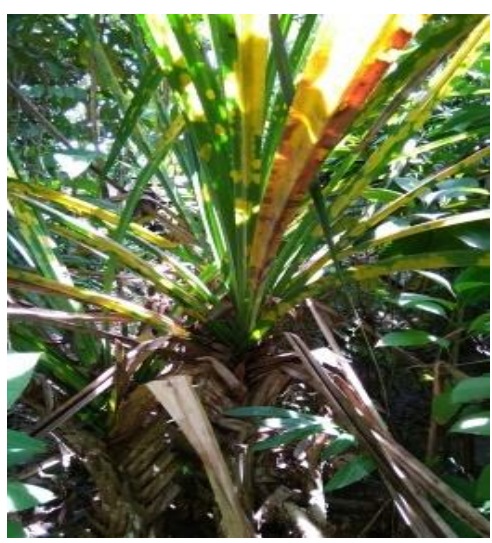

(a)

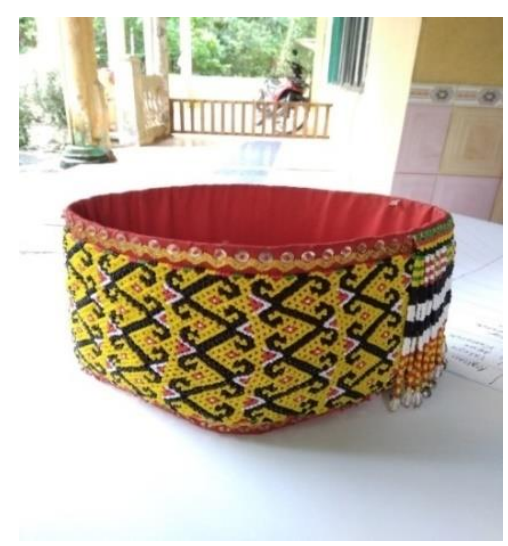

(b)

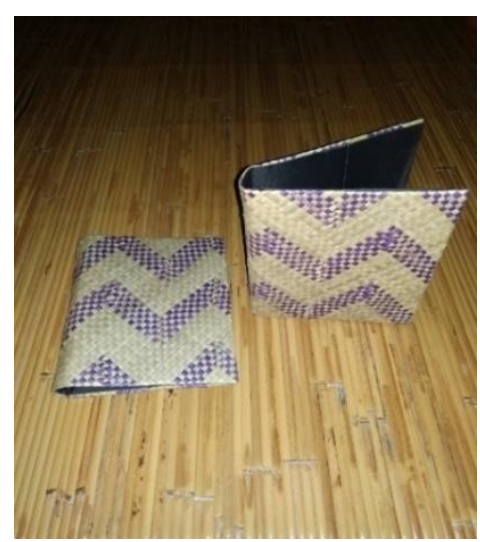

(c)

Gambar 3. Tumbuhan pandan duri dan produk kerajinan (a) Pandan duri, (b) Salaben, (c) Sampul buku (thorny pandanus plants and handicraft products (a) thorn pandanus, (b) salaben, (c) book cover)

\section{Bambu}

Bambu yang dimanfaatkan sebagai bahan kerajinan di Desa Labian sebanyak 3 jenis, yaitu bambu betung (D. asper (Schultes f.) Backer ex Heyne), bambu pering (D. asper (Schultes f.) Backer ex Heyne) dan bambu ampel ( $S$. zollingeri Steud). Bambu ampel (Gambar 4) adalah batang untuk produk kerajinan bubu dan saroak di Desa Labian dan tunasnya dikonsumsi untuk sayuran (Widjaja, 2001). Selain di buat bubu, batang dari bambu ampel dalam adat Dayak Tamambaloh dibuat talayong (tempat penyimpanan sesajen untuk roh leluhur dalam acara selamatan rumah, pemberkatan benih padi, buang pantang, tempat sesajen untuk orang yang sudah meninggal) dan nyanjarong (tempat sesajen di ladang untuk roh padi). 


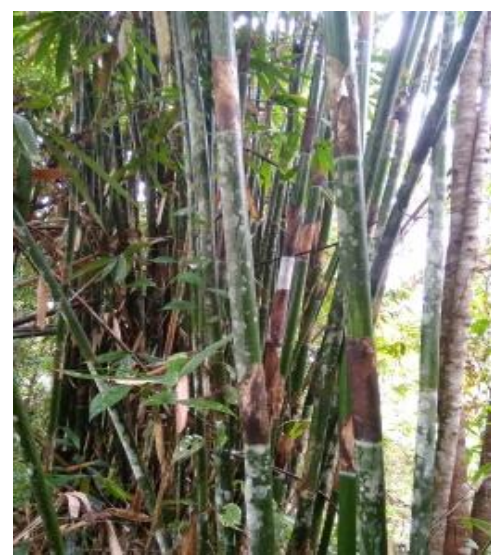

(a)

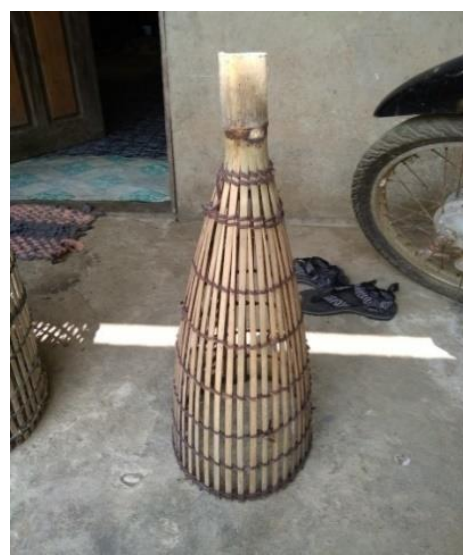

(b)

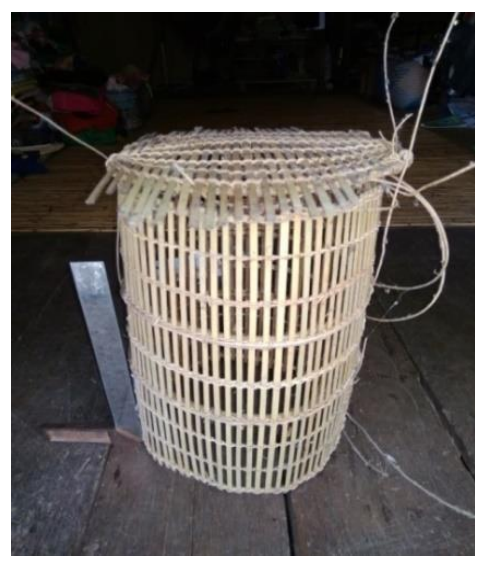

(c)

Gambar 4. Tumbuhan bambu ampel dan produk kerajinan (a) Bambu ampel, (b) Bubu, (c) Saroak (ampel bamboo plants and handicraft products (a) ampel bamboo, (b) bubu, (c) saroak)

Produk kerajinan bubu yang di buat dari satu buah ruas bambu yang ruasnya di belah menjadi beberapa bagian tanpa membuang salah satu bagian ruas. Bambu yang sudah di belah kemudian diraut untuk membuang bagian tajam dari bambu. Saat perakitan di tambahkan beberapa rautan bambu yang diikatkan/dianyam dengan bagian bambu yang masih menempel diruas, sedangkan untuk prmbuatan saroak bambu yang sudah diraut saling diikatkan dengan tali pengikat yang terbuat dari rotan.

\section{Pulai (A. scholaris $(\mathrm{L}))$}

Pulai (Gambar 5) digunakan untuk pembuatan tukuk tajak dan perisai. Penggunaan pohon pulai sebagai bahan pembuatan tukuk tajak dan perisai karena Arah seratnya lurus sampai berpadu, tekstur kayunya agak halus, rata dan sedikit mengkilap.

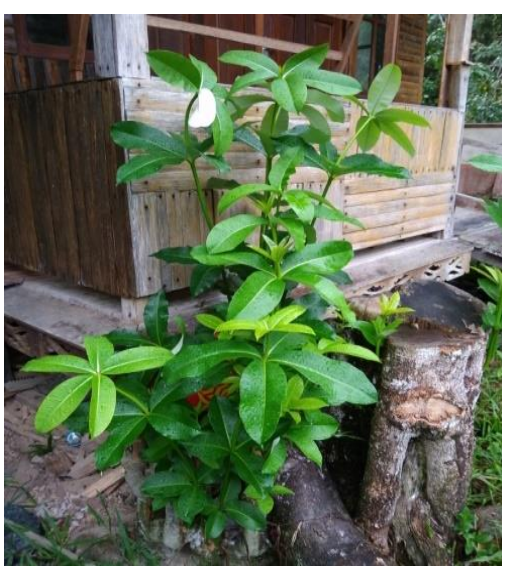

(a)

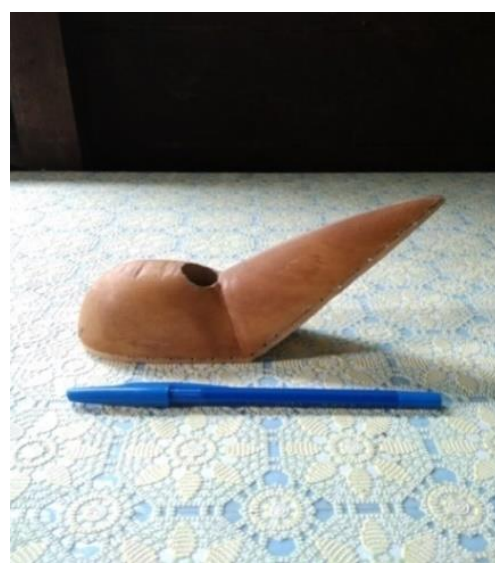

(b)

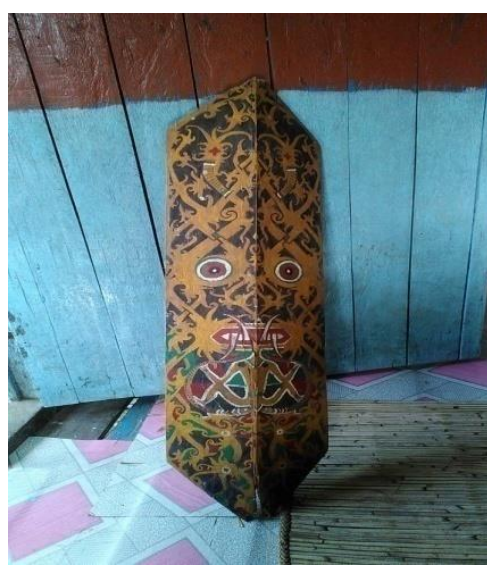

(c)

Gambar 5. Tumbuhan pulai dan produk kerajinan (a) Pulai, (b) Tukuk tajak, (c) Perisai (pulai plant and handicraft products (a) pulai, (b) tukuk tajak, (c) shield) 
Kayunya tidak menampilkan corak unik dan kayunya agak lunak, kayunya yang ringan, mudah diolah dan jika sudah kering kayu dari pohon pulai akan tahan lama dan kuat (Pandit, 2011).

\section{Rotan}

Menurut Januminro (2000) bahwa keenam jenis rotan yang di temukan di Desa Labian dapat digunakan sebagai bahan pembuatan produk kerajinan seperti Rotan sega (C. caesius Blume), rotan bubuai ( $P$. elongata Martius ex Blume), rotan korod ( $C$. heteroideus Blume), rotan dandan (C. Schistolantus
Blume), rotan dahan (K. rigida Blume), dan rotan lilin ( $C$. javensis Blume). Rotan sega (Gambar 6) oleh Dayak Tamambaloh Desa Labian digunakan sebagai bahan pembuatan keranjang, sabit dan sebagai tali pengikat, tas, bakul. Tumbuhan rotan adalah tumbuhan yang paling banyak digunakan sebagai bahan kerajinan seperti pembuatan tas rotan yang dikombinasikan dengan kain tenun dan pembuatan sabit sabagai pengankut barang yang semua bahannya terbuat dari tumbuhan rotan.

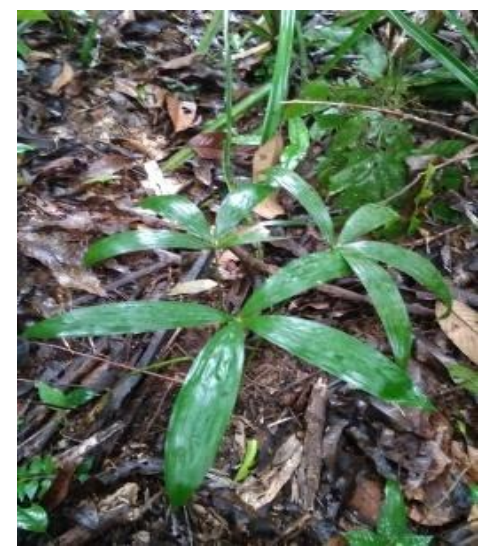

(a)

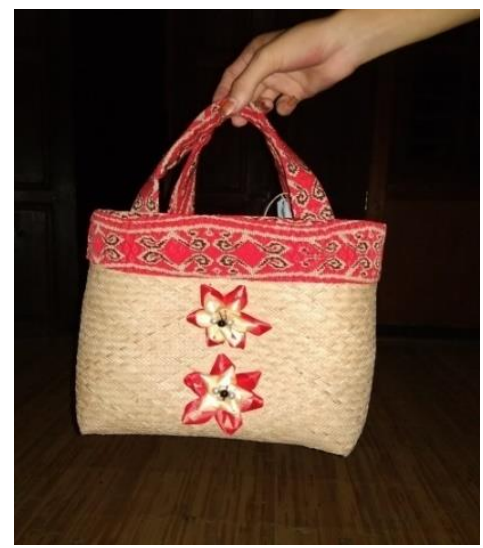

(b)

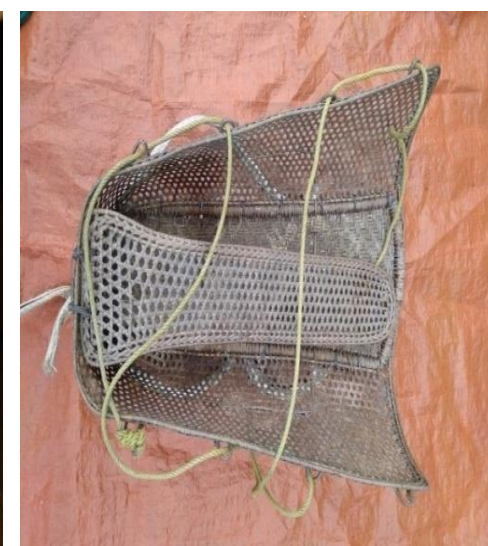

(c)

Gambar 6. Tumbuhan rotan sega dan produk kerajinan (a) Rotan Sega, (b) Tas rotan, (c) Sabit (sega rattan plants and handicraft products (a) sega rattan, (b) rattan bag, (c) sabit)

Tumbuhan yang dibutuhkan biasanya langsung diambil dari hutan, pekarangan rumah atau kebun, waktu pemgambilan disesuai kapan akan membutuhkan tumbuhan tersebut. Proses pengambilan tumbuhan tidak memerlukan ritual adat, masyarakat bisa bebas mengambil di hutan tanpa ada larangan atau pantangan. Pengawetan dari bahan dan produk kerajinan dilakukan dengan cara penjemuran dan pengasapan, dan untuk pewarnaan menggunakan pewarna alami serta cara pengolaan dari semua produk kerajinan dilakukan dengan cara dianyam. Pemanfaatan tumbuhan seperti rotan yang banyak digunakan oleh suku Dayak Tamambaloh seperti contoh untuk bahan pembuatan produk masih sering dibuat seperti produk kerajinan sabit, bahan pengikat untuk alat penangkap ikat seperti bu, bahan 
pembuatan tas, dompet, alat pengikat untuk baka'k, aga'k, bahan utama pembuatan keranjang. Penelitian yang dilakukan oleh Jumiati (2012) pada suku Anak dalam di Dusun Semani III Desa Jebak Kabupaten Batanghari Jambi jenis terdapat 12 jenis anyaman kreasi yang terbuat dari rotan seperti ambung, tanggok, keruntung, tengkalang, lukah, nyiru, bakul, panepok lalat, lekar, wadah ikan, dan cincin pengikat. Tumbuhan yang digunakan sebagai bahan kerajinan dalam pengambilan tumbuhannya dilakukan pada saat tumbuhan tersebut diperlukan saja.

Produk kerajinan yang dapat dihasilkan dari tumbuhan hutan oleh suku Dayak Tamambaloh sebanyak 47 jenis. Produk kerajinan yang paling banyak diproduksi adalah gantungan kunci, kalung, antin-antin dan gelang karena dalam pembuatanya yang mudah dan tidak membutuhkan waktu yang lama Produk kerajinan dijual dengan harga Rp.5000-Rp.50000. Jabang/perisai adalah produk yang paling jarang dibuat oleh para pengerajin karena pemasaran dan pesanan sangat sedikit. Sejauh ini belum ada upaya yang dilakukan untuk meningkatkan penjualan produk dan pendapat para pengrajin.

\section{KESIMPULAN}

Suku Dayak Tamambaloh memanfaatkan 22 jenis tumbuhan hutan sebagai bahan kerajinan menghasilkan 47 jenis kerajinan. Hampir semua jenis kerajinan dibuat dengan cara dianyam. Produk kerajinan yang dihasilkan oleh masayarakat Dayak Tamambloh dari tumbuhan hutan selain untuk dijual juga digunakan untuk mempermudah pekerjaan seperti alat keperluan rumah tangga, alat penamgkap ikan, hiasan, serta untuk ritual adat dan pakaian adat.

\section{SARAN}

1. Perlunya pembudidayaan semua jenis tumbuhan yang dimanfaatkan sebagai bahan produk kerajinan

2. Perlunya promosi ke media sosial semua produk yang dihasilkan oleh para pengrajin agar lebih dikenal oleh masyarakat luas.

\section{DAFTAR PUSTAKA}

Irawanto R, Lestari DA, Hendrian R. 2017. Jali (Coix lacryma-jobi L.): Seeds, germination, and its potential. In Prosiding Seminar Nasional Masyarakat Biodiversitas Indonesia Vol. 3, No. 1, pp. 147-153

Januminro. 2000. Rotan Indonesia, Potensi, Budi Daya, Pemungutan, Pengolahan, Standar Mutu, dan Prospek Penguusahaan. Yogyakarta: BPFE

Jumiati J, Hariyadi B, Murni P. 2012. Studi Etnobotani Rotan Sebagai Bahan Kerajinan Anyaman Pada Suku Anak Dalam (SAD) di Dusun III Senami, Desa Jebak, Kabupaten Batanghari, Jambi. Biospecies 5(1) : 33-41

Liberani C. 2016. Masyarakat Adat Dayak Tamambaloh. http://claudialiberani. Com/2016/03/masyarakat-adatdayak-tamambaloh.html (20 Mei 2018)

Liyanti PR, Budhi S, Yusro F. 2015. Studi Etnobotani Tumbuhan Yang 
Dimanfaatkan Di Desa Pesaguan Kanan Kecamatan Matan Hilir Selatan Kabupaten Ketapang. Jurnal Hutan Lestari, Vol. 3 (3) : $421-433$

Nono, Diba F, Fahrizal. 2017. Pemanfaatan Hasil Hutan Bukan Kayu Oleh Masyarakat Di Desa Labian Ira'ang Dan Desa Datah Diaan Di Kabupaten Kapuas Hulu. Junal Hutan Lestari. Vol. 5 (1) : $76-87$

Pandit IK, Nandika D, Darmawan IW. 2011. Analisis sifat dasar kayu hasil hutan tanaman rakyat.

Jurnal Ilmu Pertanian Indonesia, 16(2), 119-124.

Patwanto P. 2012. Makna Simbolis Perisai Dayak Bukit di Kecamatan Senga Temila Kabupaten Landak Kalimantan Barat (Doctoral dissertation Universitas Negeri Yogyakarta).

Sihombing JA. 2011. Pemanfaatan Hasil Hutan Bukan Kayu (HHBK)
Oleh Masyarakat Desa Sekitar Hutan di IUPHHK-HA PT. Rata Timber Samarinda Kalimantan Timur. Bogor Agricultural University. http://repository. Ipb.ac.id/jspui/bitstream/1234567 89/51887/1/E11jas.pdf ( 8 Mei 2018)

Sudana DN. 2017. Ibm Pengerajin Pandan Berduri di Desa Tumbu Karangasem Laksana, 1(1), 12-22

Syukur M. 2017. Kerajinan Tangan Hasil Pengolahan Tumbuhan Hutan Oleh Masyarakat Desa Nibung Kecamatan Selimbau Kabupaten Kapuas Hulu. Publikasi Informasi Pertanian, PIPER No.24 Volume 13 April 2017

Widjaja, EA. 2001. Identifikasi JenisJenis Bambu Di Jawa. Bogor: LIPI 